УДК 656:657.4

\title{
УДОСКОНАЛЕННЯ ТРАНСПОРТНОГО ОБСЛУГОВУВАННЯ ЯК ФАКТОР ЗАБЕЗПЕЧЕННЯ ТОВАРНИХ ХАРАКТЕРИСТИК ПРОДУКЦІї
}

\author{
Каличева Н.С., о.е.н., доцент, \\ Маслова В.О., к.е.н., доцент (УкрДУЗТ)
}

\begin{abstract}
Транспорт $\epsilon$ одним із ключових елементів логістичної системи, котрий відповідає за забезпечення ефективного просування потоку вантажів із пункту відправки до пункту призначення. Своєчасне перевезення вантажів у прочесі виробництва та реалізації продукції значною мірою впливає на формування виробничого ланцюга $і$ забезпечення товарних характеристик виробленої продукиії. У статті обтрунтовано вибір операційних стратегій транспортного обслуговування, а саме стратегія зниження витрат на транспортування, стратегія удосконалення управління прочесом перевезення, стратегія підвищення якості транспортних операчій для забезпечення товарних характеристик продукиії, яка перевозиться.
\end{abstract}

Ключові слова: товар, вантаж, транспортний процес, обслуговування, збереження, транспортні підприємства, фактори впливу, стратегія

\section{СОВЕРШЕНСТВОВАНИЕ ТРАНСПОРТНОГО ОБСЛУЖИВАНИЯ КАК ФАКТОР ОБЕСПЕЧЕНИЯ ТОВАРНЫХ ХАРАКТЕРИСТИК ПРОДУКЦИИ}

\author{
Каличева Н.Е., д.э.н, доцент, \\ Маслова В.А., к.э.н., доцент (УкрГУЖТ)
}

\begin{abstract}
Транспорт является одним из ключевых элементов логистической системы, который отвечает за обеспечение эффективного продвижения потока грузов из пункта отправки в пункт назначения. Своевременная перевозка грузов в процессе производства и реализачии продукции в значительной мере влияет на формирование производственной иели и обеспечения товарных характеристик продукции. В статье обоснован выбор операционных стратегий транспортного обслуживания, а именно стратегия снижения расходов на транспортировку, стратегия совершенствования управления прочессом перевозки, стратегия повышения качества транспортных операций для обеспечения товарных характеристик перевозимой продукции.
\end{abstract}

Ключевые слова: товар, груз, транспортный процесс, обслужсивание, хранение, транспортные предприятия, факторы влияния, стратегия

\section{IMPROVEMENT OF TRANSPORT SERVICES AS A FACTOR OF PROVIDING PRODUCT CHARACTERISTICS OF PRODUCTS}

Kalicheva N.E., doctor of economic sciences, associate professor, Maslova V.O., candidate of economic sciences, associate professor (USURT)

The process of delivery of goods between different consumer groups requires quality preparation and transport plays an important role in this process. Transport service is limited not only to ensuring the process of moving goods between manufacturers and consumers,

(C) Каличева Н.Є., Маслова В.О.

Вісник економіки транспорту і промисловості № 69, 2020 
providing vehicles, maintaining routes, but also determining distances and times of domestic transportation, providing raw materials, processing materials and products of markets. Proper organization of transportation, the availability of reliable rolling stock at transport enterprises has a significant impact on the timely completion of the production cycle, increasing productivity and reducing the cost of production. Therefore, reliable transport service of enterprises is not only the process of ensuring the continuity and rhythm of production, but also the process of logistically ensuring the commodity characteristics of products on the path of its passage from producer to consumer. In general, both the external and internal environmental factors influence the transport service process. All these factors must be taken into account when developing an operational transportation service strategy to ensure product performance, which should be presented in the form of a long-term program of specific actions to plan and execute a set of transport operations in order to optimize the use of available transportation resources to ensure transportation efficiency and cost of this certain competitive advantage. Operational strategies for transportation services should be based on a strategy of reducing transportation costs, a strategy for improving the management of the transportation process, and a strategy for improving the quality of transport operations. The proposed operational strategies should be consistent with the overall corporate strategy of the transport company, be complementary, realistic and effective to ensure its effective operation. In particular, when assessing the efficiency of transport services, it is necessary to take into account the quality of transportation, the impact of transport work on the quality of goods and ensure the preservation of their product characteristics in the process of moving from producer to consumer.

Key words: goods, cargo, transport process, service, storage, transport enterprises, influence factors, strategy

\begin{abstract}
Постановка проблеми та ї̈ зв'язки з науковими чи практичними завданнями. Процес доставки товарів між різними групами споживачів потребує якісної підготовки і важливу роль в цьому процесі займає транспорт [1]. Транспортне обслуговування зводиться на лише до забезпечення процесу переміщення вантажів між виробниками та споживачами, надання транспортних засобів, утримання шляхів сполучення, а й визначення відстаней та часу внутрішньогосподарських перевезень, забезпечення сировиною, матеріалами місць переробки та продукцією ринків збуту.
\end{abstract}

Правильна організація перевезень, наявність на транспортних підприємствах надійного рухомого складу має значний вплив на своєчасне завершення виробничого циклу, збільшення продуктивності праці та зменшення собівартості продукції. Тож надійне транспортне обслуговування підприємств
- це не лише процес забезпечення безперервності та ритмічності виробництва, а й процес логістичного забезпечення товарознавчих характеристик продукції на шляху іiі проходження від виробника до споживача. Аналіз останніх досліджень $\boldsymbol{i}$ публікацій. Питання дослідження транспортного обслуговування розкрито у наукових працях Галабурди В.Г., Диканя В.Л., Крикавського С., Перебийноса О.В. Токмакової І.В. та інших [2-6]. Наголошуючи на науковій та практичній цінності сформованих теоретикометодологічних та прикладних розробок зазначених вчених, необхідно відзначити, що питання транспортного обслуговування виробничих процесів та комерційної діяльності потребують більш широкого охоплення під впливом сучасних економічних процесів для забезпечення товарних характеристик продукції шляхом формування операційної стратегії транспортного 
обслуговування, забезпечення високої якості транспортних процесів, тощо.

Mema cmammi. На основі аналізу факторів зовнішнього та внутрішнього середовища, які мають вплив на якість транспортного обслуговування, обгрунтувати складові оперативних стратегій ефективного розвитку підприємств транспорту для забезпечення товарознавчих характеристик перевезених вантажів.

Виклад основного матеріалу дослідження. Вибір транспортного засобу для переміщення товарів має грунтуватися на його потужності та спроможності перевезти необхідний товар не пошкодивши його та враховувати наступні чинники:

- технічні обмеження, що грунтуються на габаритних, фізичних, хімічних, біологічних та інших особливостях товарів;

- терміни доставки, які формуються згідно зі строком придатності товару та термінами конкретних технологічних процесів, в котрих товар приймає участь;

- дотримання вимог безпеки та збереження споживчих якостей товарів;

- дистанція та напрям переміщення;

- вартість перевізної роботи та інші транспортні витрати.

Загалом, на процес транспортного обслуговування мають вплив як фактори зовнішнього, так і внутрішнього середовища (рис. 1).

Зниження кількості витрат при значній оперативності, надійності та стабільності перевізного процесу 3 доставки товару від виробника до споживача $є$ однією 3 основ ефективного транспортного обслуговування [7]. За таких умов, доставка товарів має здійснюватися чітко, відповідно до встановлених термінів. Кількість товару має відповідати замовленню. У процесі перевезення не має пошкодитися товар [8].

При збереженні та транспортуванні деяких видів вантажів в наслідок наявних у них фізико-хімічних та біологічних властивостей може відбутися зміна їхньої ваги, обсягу або структурної цілісності. Неминучі товарні втрати вантажів залежать від умов та часу здійснення процесу транспортування (навантаження, перевезення, збереження, зокрема на проміжних складах, вивантаження) та відносяться до природних втрат.

Природна втрата вантажів під час реалізації перевізного процесу нормується. Норми формуються відповідними нормативними актами та положеннями, є контрольними та відповідають тим максимальним розмірам природних втрат, за які не несе відповідальність транспортне підприємство. Але списання втрат має суворо контролюватися та відбуватися відповідно до фактичних втрат, на що мають бути оформлені відповідні нормативні документи (акти).

До основних причин, які призводять до природних втрат вантажів, відносять усушку, вивітрювання, вбирання тарою, витік, просочування, випаровування, розтрушування та розпорошування, бій скляної тари, скляних, фарфорових та фаянсових виробів, тощо. При транспортуванні штучних вантажів та фаянсових товарів по розрахунку норми природних втрат не включаються. Пошкодження тари, а також різниця між фактичною масою тари та масою за трафаретом до норми витрат не включаються. Норми природних втрат при транспортуванні встановлюють у відсотках до початкової маси чи обсягу вантажу (нетто). При розрахунку норми зважають на дальність перевезення, пору року, способи транспортування (тара чи насипом), використання певного виду рухомого складу відповідно до виду вантажу. Норми витрат встановлюються лише для перевезення деяких видів вантажів, затарених у скляний посуд, а також для перевезення скляного пустого посуду. 


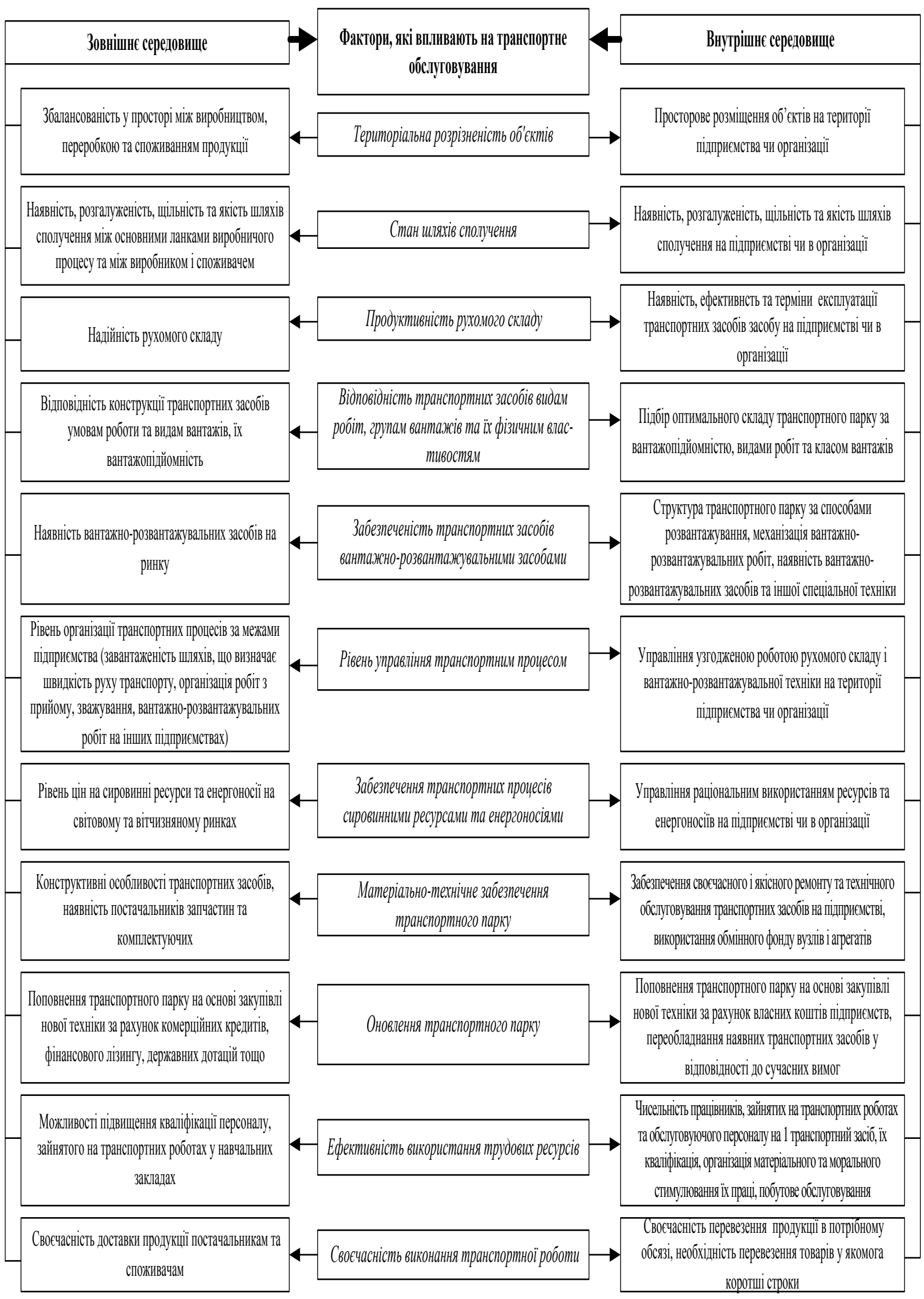

Рис. 1 Фактори впливу внутрішнього та зовнішнього середовища на якість транспортного обслуговування

Вісник економіки транспорту і промисловості № 69, 2020 
Однією 3 важливих умов перевезення товарів є повне збереження їх якості та кількості [9]. Тому вирішальне значення має спроможність рухомого складу пристосуватися до перевезення певного виду вантажів, його укладання в транспортному засобі, кріплення, закриття, відповідність швидкості руху умовам транспортування та обачливість під час здійснення вантажнорозвантажувальних операцій.

У транспортному засобі вантаж має бути розташований у такий спосіб, щоб не перевищувати допустиму вантажність та осьове навантаження для забезпечення стійкості при гальмуванні, прискоренні та зміні напряму руху, особливо це стосується автомобільних перевезень.

Кріплення вантажів виконується мотузками, ременями, трасами, ланцюгами або 3 використанням інших спеціальних пристосувань (комплектів, пристроїв, деталей). Для кріплення на платформах та бортових кузовах мають бути пристосування для використання крюків або інших кріпильних елементів. Bci кріпильні елементи повинні мати значний запас міцності (не менше 3-х кратного). Закріплений вантаж не повинен рухатися під час процесу транспортування.

Всі ці фактори необхідно враховувати при розробці операційної стратегіï транспортного обслуговування для забезпечення товарних характеристик продукції, котра має бути представлена у вигляді довгострокової програми конкретних дій щодо планування та виконання сукупності транспортних операцій 3 метою оптимального використання наявних транспортних ресурсів для забезпечення ефективності транспортного обслуговування та отримання за рахунок цього певних конкурентних переваг [10].

Таким чином, в основу операційних стратегій транспортного обслуговування мають бути покладені стратегія зниження витрат на транспортування, стратегія удосконалення управління процесом перевезення, стратегія підвищення якості транспортних операцій (рис. 2).

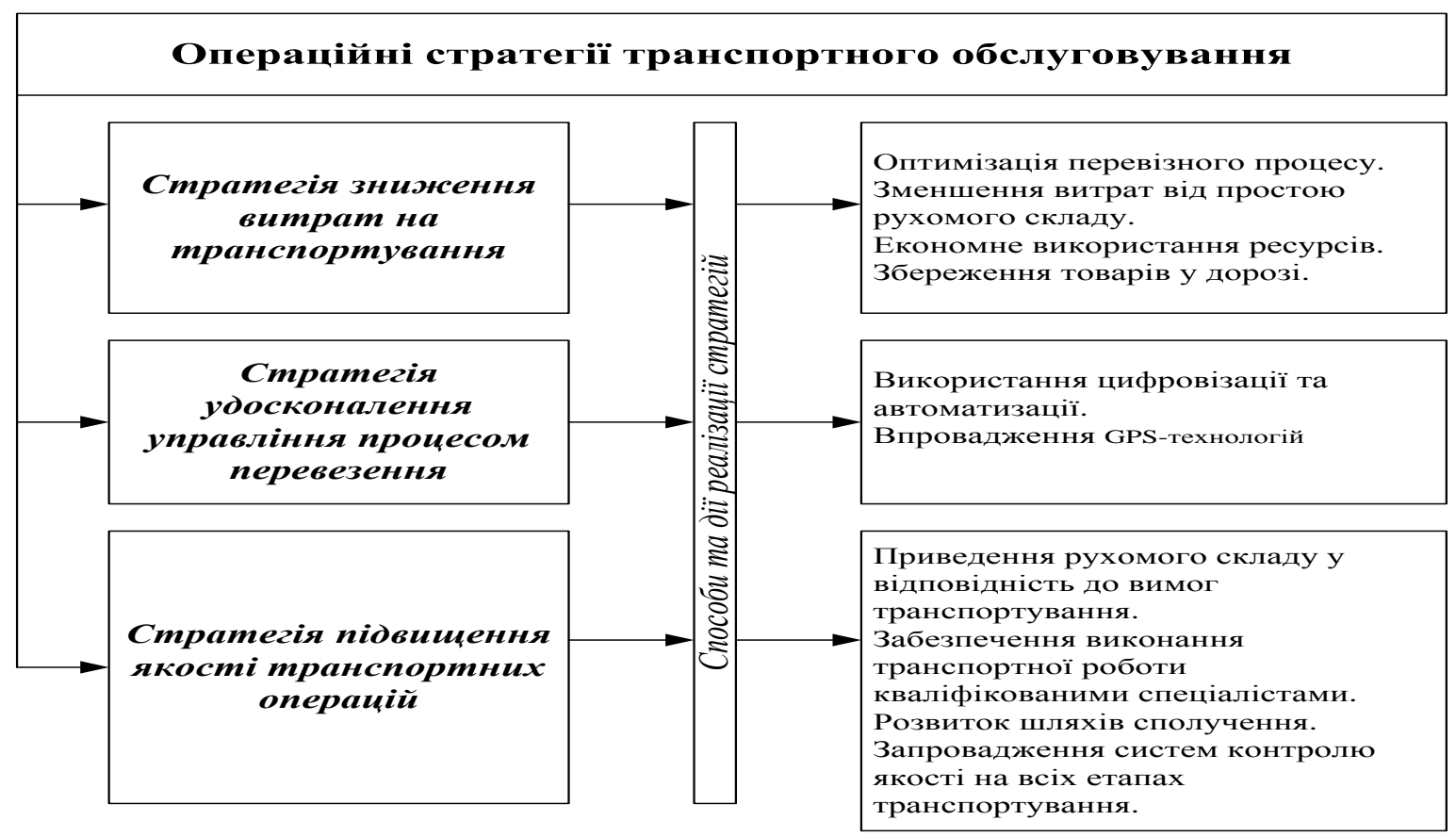

Рис. 2 Ключові операційні стратегії транспортного обслуговування 
Запропоновані операційні стратегії мають відповідати загальній корпоративній стратегії транспортного підприємства, бути взаємодоповнюючими, реалістичними та результативними для забезпечення його ефективної роботи. Зокрема, при оцінці ефективності транспортного обслуговування необхідно враховувати якість транспортування, вплив транспортної роботи на споживчі властивості вантажів та забезпечення збереження їхніх товарних характеристик в процесі переміщення від виробника до клієнта.

Висновки. Транспортна політика та стратегія розвитку перевізного підприємства мають грунтуватися на сьогочасних та майбутніх потребах й очікуваннях зацікавлених сторін у сфері транспортного обслуговування виробництва та збуту продукції.

На базі аналізу потреби в транспортних засобах та визначенні, які саме фактори впливають на зниження ефективності транспортного обслуговування, необхідно знижувати витрати на перевезення, оптимізувати перевізний процес шляхом удосконалення його управління та підвищувати якість транспортної роботи. Це дозволить оптимізувати роботу транспортних підприємств у сфері забезпеченні товарознавчих характеристик продукції та бути конкурентними на ринку.

\section{ПЕРЕЛІК ВИКОРИСТАНОЇ ЛІТЕРАТУРИ}

1. Дикань В.Л., Каграманян А.О., Каличева Н.Є., Маковоз О.В., Сухорукова Т.Г. Товарознавство та комерційна діяльність: підручник. Харків: УкрДУЗТ, 2018. 362 c.

2. Галабурда В. Г., Соколов Ю. И. Комплексная оценка качества транспортного обслуживания. Железнодорожный транспорт. 1999. № 5. C. 60-64.
3. Дикань В. Л., Корінь М. В. Ефективність роботи транспортної системи України в умовах глобалізації економічних систем. Вісник економіки транспорту і промисловості. 2011. № 33. C. 13-19.

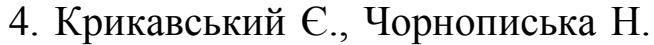
Україна у глобальних ланцюгах поставок. Логістика: теорія та практика. 2012. № .1. C. $92-100$.

5. Перебийніс О. В. Методичні основи формування ринку транспортних послуг. Вісник Харківського начіонального технічного університету сільського господарства ім. П. Василенка: Економічні науки. Ринкова трансформачія економіки АПК. 2004. Вип. 32. С. 376-380.

6. Токмакова I. В. Сучасні аспекти формування ефективної системи управління на підприємствах залізничного транспорту. Вісник економіки транспорту і промисловості. 2013. № 42. С. 393 - 395.

7. Каличева Н. С. Роль транспорту у забезпечення ефективності
функціонування маркетингово-товарнологістичної схеми підприємства. Вісник економіки транспорту $i$ промисловості. 2016. № 56. С. 93-96.

8. Воловельська I. В., Маслова В. О. Дослідження факторів, що впливають на поведінку споживачів в сучасних умовах. Вісник економіки транспорту $i$ промисловості. 2018. №61. С.117-123.

9. Полякова О. М., Шраменко О. В. Сучасні тенденції розвитку транспортнологістичної інфраструктури в Україні i світі. Вісник економіки транспорту $i$ промисловості. 2017. № 58. С. 126-134.

10. Каличева Н. С. Методологічні аспекти підвищення конкурентоспроможності підприємств залізничного транспорту за рахунок управління конкурентними позиціями. Науковий вісник Херсонського державного університету. Сер.: Економічні науки. Херсон, 2017. Вип. 27. Ч. 1. С. 139 - 142. 


\section{REFERENCES}

1. Dy`kan` V.L., Kagramanyan A.O., Kaly`cheva N.Ye., Makovoz O.V., Suxorukova T.G. (2018). Tovaroznavstvo ta komercijna diyal'nist. [Merchandise and business] Kharkiv: UkrDUZT. (in Ukrainian).

2. Galaburda V.G.. Sokolov Yu.I. (1999) Kompleksnaya otsenka kachestva transportnogo obsluzhivaniya [Comprehensive assessment of the quality of transport services]. Zheleznodorozhnyy transport, no 5, pp. 60-64. (in Russian)

3. Dykanj V. L., Korinj M. V. (2011). Efektyvnistj roboty transportnoji systemy Ukrajiny $\mathrm{v}$ umovakh ghlobalizaciji ekonomichnykh system. [The efficiency of the transport system of Ukraine in the conditions of globalization of economic systems]. Bulletin of the Economy of Transport and Industry: a collection of scientific and practical articles. Kharkiv: UkrDazt. No. 33, pp. 13-19.

4. Krikavsky Ye., Chernopyska N. (2012) Ukrajina u ghlobaljnykh lancjughakh postavok [Ukraine in global supply chains]. Logistics: Theory and Practice. No 1, pp. 92100

5. Perebyinis O.V. (2004), "Methodical foundations of market formation of transport services“, Visnyk Kharkivskoho natsionalnoho tekhnichnoho universytetu silskoho hospodarstva im. P. Vasylenka: Ekonomichni nauky. Rynkova transformatsiia ekonomiky APK, issue 32, pp. 376-380.

6. Tokmakova I.V. (2013) Suchasni aspekty formuvannya efektyvnoyi systemy upravlinnya na pidpryyemstvakh zaliznychnoho transportu [Modern aspects of the formation of an effective management system at railway enterprises]. Bulletin of Economics of Transport and Industry. no. 42, pp. 393 - 395 .

7. Kaly`cheva N. Ye. (2016). Rol transportu u zabezpechennya efekty`vnosti funkcionuvannya markety`ngovo-tovarnologisty`chnoyi sxemy` pidpry`yemstva. [The Role of Transport in Ensuring the Effectiveness of the Company's Marketing and Commodity Scheme] Bulletin of the Economics of Transport and Industry, vol. 56, pp. 93-96.

8. Volovelska I.V., Maslova V.O. (2018) Doslidzhennia faktoriv, shcho vplyvaiut na povedinku spozhyvachiv $\mathrm{v}$ suchasnykh umovakh [Investigation of the factors influencing consumer behavior in modern conditions]. Visnyk ekonomiky transportu $i$ promyslovosti, no.61, pp.117123. transportno-loghistychnoji infrastruktury $\mathrm{V}$ Ukrajini i sviti [Current Trends in the Development of Transport and Logistics Infrastructure in Ukraine and in the World]. Bulletin of the Economics of Transport and Industry, vol. 58, pp. 126-134.

10. Kaly`cheva N. Ye. (2017) Metodologhichni aspekty pidvyshhennja konkurentospromozhnosti pidpryjemstv zaliznychnogho transportu za rakhunok upravlinnja konkurentnymy pozycijamy [Methodological aspects of increasing the competitiveness of railway companies through the management of competitive positions]. Scientific Herald of Kherson State University. Series: Economic Sciences, vol. 27, no 1, pp. $139-142$. 